\title{
CHRYSTUS LEKARZEM I LEKARSTWEM Z NIEBA W ŚWIETLE HOMILII ŚW. AUGUSTYNA DO EWANGELII I PIERWSZEGO LISTU JANA APOSTOLA
}

Analizując Augustynowe nauczanie, zawarte w In Joannis Evangelium tractatus oraz In Iohannis Epistolam ad Parthos tractatus ${ }^{1}$,można zauważyć, że Autor homilii wiele miejsca poświęca zagadnieniu duchowej choroby człowieka, którą jest szeroko rozumiany grzech ${ }^{2}$. Wyjaśniając tę kwestię, Biskup Hippony poucza także swoich słuchaczy o możliwości uzdrowienia z tego rodzaju choroby. Punktem wyjścia w nauczaniu Autora homilii na ten temat są interpretowane alegorycznie teksty biblijne, które - jak zauważa A. Paciorek - w pracach egzegetycznych Augustyna stanowią niejako pretekst dla roztrząsania dość osobliwych zagadnieńn ${ }^{3}$.

Idea duchowego ,uzdrowienia”, czy też „uleczenia” człowieka została zasadniczo wyrażona przez Biskupa Hippony za pomocą czasowników: „sanare” „,uzdrowić”, „leczyć” oraz „curare” - „leczyć”s. Autor homilii posługuje się także formą rzeczownikową: ,,sanatio" - ,uzdrowienie”, ,uleczenie", oraz ,salus” - „zdrowie”, „wyzdrowienie”8 i „sanitas” - „leczenie”, „,uzdrowienie”, ,przy-

\footnotetext{
${ }^{1}$ Por. Augustinus, In Joannis Evangelium tractatus CXXIV, ed. R. Willems, CCL 36, Turnholti 1954; In Joannis Epistolam ad Parthos tractatus X, PL 35, 1977-2062, lub Commentaire de la première Épitre de S. Jean. Texte, introduction, traduction et notes P. Agaësse, SCh 75, Paris 1961, lub Commento al Vangelo e alla Prima Epistola di San Giovanni, introd. A. Vita, trad. e note E. Gandolfo, NBA 24/1-2, Roma 1968: thum. W. Szołdrski - W. Kania, PSP 15/1-2, Warszawa 1977 (w artykule posługujemy się wydaniami NBA i PSP).

${ }^{2}$ Por. szerzej G.M. Baran, Motyw choroby w homiliach św. Augustyna do Ewangelii i Pierwszego Listu Jana Apostoła, VoxP 29 (2009) t. 53-54, 541-561.

${ }^{3}$ Por. A. Paciorek, Św. Augustyn egzegeta, TST 12 (1993) 176. A Eckmann (Pismo Święte w życiu i nauczaniu Ojców Kościoła, AK 71:1979, t. 92, nr 421, 210) zauważa, że w komentowaniu Biblii Augustyn kierował się zasadniczo względami duszpasterskimi.

${ }^{4}$ Por. Stownik łacińsko-polski, t. 1-2, red. J. Korpanty, Warszawa 2001-2003, spec. t. 2, 683; por. także Słownik łacińsko-polski, t. 5, red. M. Plezia, Warszawa 1998-1999, spec. t. 5, 29-30.

${ }^{5}$ Por. Plezia, t. 1, s. 818; Korpanty, t. 1, s. 469-470.

${ }^{6}$ Por. In Joannis Evangelium tractatus 110, 6, NBA 24/2, 1478.

${ }^{7}$ Plezia, t. 5, 24.

${ }^{8}$ Por. Korpanty, t. 2, 680; Plezia, t. 5, 20.
} 
wracanie zdrowia" ", która w kontekście Augustynowego wykładu może być rozumiana jako dar udzielonego zdrowia, czyli - w sensie szerszym - uleczenie ${ }^{10}$.

Jak zauważa Augustyn, człowiek, chociaż obciążony jest z własnej winy duchowymi dolegliwościami, nie jest w stanie sam sobie pomóc: potrzebuje szczególnego rodzaju lekarza i lekarstwa. Tym lekarzem, a zarazem lekarstwem, jest Jezus Chrystus, Jednorodzony Syn Boży, który realizując Boży plan miłości względem człowieka, przyjął ludzką naturę i dokonał dzieła zbawiania, aby przez to człowiek, uwolniony od duchowych ułomności i dolegliwości, osiągnął stan duchowego zdrowia.

\section{JEZUS LEKARZEM CHORYCH}

Analiza tekstów Augustynowego nauczania pozwala zauważyć, że wielokrotnie Autor homilii określa Jezusa Chrystusa mianem lekarza - „medicus”. W homilii do IV Ewangelii pojawia się nawet stwierdzenie:

„On jest cały naszym lekarzem, jest nim rzeczywiście" ${ }^{11}$.

Chociaż Augustyn nie mówi o tym wprost, to jednak wydaje się, iż przytoczone zdanie ma na celu wyeksponować prawdę o tym, że cały Chrystus - zarówno jako prawdziwy Bóg, jak i prawdziwy Człowiek - jest lekarzem człowieka.

Człowiek dotknięty różnego rodzaju chorobami potrzebował i nadal potrzebuje uzdrowienia. $Z$ tej racji Augustyn stwierdza, że „,nikt się tu nie urodził, któremu ten lekarz nie byłby potrzebny" ${ }^{2}$. Wszyscy bowiem ludzie dotknięci są chorobą już z racji naturalnych narodzin, poprzez które dziedziczą chorobę praojca Adama, czyli grzech pierworodny. Dlatego Autor homilii z naciskiem stwierdza: „Jesteśmy chorzy”, aby niejako podkreślić, że stan choroby dotyczy każdego bez wyjątku' ${ }^{13}$.

Jezus Chrystus zatem jako Jednorodzony Syn Boży przyjął ludzką naturę i przybył na ziemię, aby jako lekarz leczyć ludzi ze wszelkich dolegliwości, dotyczących zarówno sfery ciała, jak i sfery ducha. $Z$ tej racji Autor homilii mówi o Jezusie jako o „lekarzu dusz i ciał” (medicus et animarum et corporu$m)^{14}$. Przyjmując ludzką naturę, Jezus przybył do wszystkich ludzi bez wyjątku; nie tylko do tych, którzy w Niego uwierzyli, lecz także do „bezbożników” oraz „niewierzących”"15. Chrystus jako lekarz przybył zarówno do „swojej

\footnotetext{
${ }^{9}$ Por. Korpanty, t. 2, 681; Plezia, t. 5, 24.

${ }^{10}$ Por. In Joannis Evangelium tractatus 6, 15, NBA 24/1, 138; zob. także 17, 7, NBA 24/1, 400;

17, 10, NBA 24/1, 404; 18, 13, NBA 24/1, 406.

${ }^{11}$ Tamże 3, 3, NBA 24/1, 46, PSP 15/1, 53.

${ }^{12}$ Tamże 7, 18, NBA 24/1, 176, PSP 15/1, 126.

${ }^{13}$ Por. tamże 2, 8, NBA 24/1, 34.

${ }^{14}$ Por. tamże 17, 1, NBA 24/1, 390.

${ }^{15}$ Por. In Joannis Epistolam ad Parthos tractatus 2, 1, NBA 24/2, 1664.
} 
własności” (J 1, 11), czyli do swojej ojczyzny - narodu izraelskiego ${ }^{16}$, jak i do pogan, których symbolem, według Augustyna, jest uzdrowiona z krwotoku kobieta (por. Mt 9, 20-22; Mk 5, 25-34; Łk 8, 42-48) ${ }^{17}$.

Przybycie Jezusa jako lekarza dokonało się niejako wbrew powszechnej praktyce, gdyż - jak zauważa Autor homilii, odwołujący się do codziennego doświadczenia - to zwykle człowiek chory szuka lekarza i udaje się do niego. W przypadku natomiast Chrystusa to właśnie On sam przybył na ziemię, aby szukać i uzdrawiać chorych ${ }^{18}$. Jako argument biblijny można za Augustynem przywołać słowa zaczerpnięte z J 3, 17:

„Bo nie posłał Bóg Syna swego na świat, aby świat sądził, ale aby świat był zbawiony przez Niego" ${ }^{\prime \prime}$.

Komentując tę wypowiedź Jezusa, Autor homilii stwierdza: „A więc po to przybył lekarz, aby uzdrowić chorego" ${ }^{20}$. A zatem nie od chorego wyszła inicjatywa, aby lekarz go uzdrowił, ale to właśnie sam lekarz - Jezus Chrystus przybył, aby uzdrowić.

Analizując nauczanie Augustyna, można zauważyć, że Autor homilii zwraca uwagę zarówno na uzdrowienia $z$ duchowych chorób, jak i na uleczenia fizycznych dolegliwości. Te ostatnie jednak traktuje niejako marginalnie, gdyż ogranicza się do podania jedynie informacji o tym, jakich chorych, czy też jakie choroby Jezus uleczył. W tym kontekście Augustyn uczy, że w ziemskim życiu Chrystus ,ślepych oświecał, głuchym uszy otwierał, niemowom rozwiązywał usta, członki paralityków uzdrawiał" 21 . W innym miejscu swego nauczania, stwierdzając, że Jezus przybył tam, gdzie było mnóstwo chorych, wylicza natomiast bardzo pobieżnie poszczególne grupy chorych, którzy doznali uzdrowienia. Mówi zatem o ślepych, kulawych, i suchotnikach ${ }^{22}$. Wzmiankuje także dokonane przez Jezusa oczyszczanie z trądu, przywracanie słuchu, wzroku, czy też mowy ${ }^{23}$, oraz uzdrawianie wielu kalectw, chorób i udręk śmiertelnych ${ }^{24}$.

Mówiąc o zdrowiu fizycznym, które jest udzielane człowiekowi, lub przywracane, kiedy człowiek jest chory, Autor homilii stwierdza nadto, że nie tylko ludziom Bóg udziela tego daru, ponieważ także każdemu zwierzęciu Bóg daje zdrowie, zgodnie z słowami Ps 35, 7: „Ludzi i zwierzęta wybawiasz, Panie; jak-

\footnotetext{
${ }^{16}$ Por. np. In Joannis Evangelium tractatus 16, 3-7, NBA 24/1, 380-388.

${ }^{17}$ Augustyn stwierdza, że uzdrowiona $\mathrm{z}$ krwotoku kobieta jest figurą Kościoła, mającego powstać z pogaństwa, por. tamże 31, 11, NBA 24/1, 682 .

${ }^{18}$ Por. tamże 7, 21, NBA 24/1, 182; tamże 2, 7, NBA 24/1, 32.

${ }_{19}$ Tamże 12, 12, NBA 24/1, 292: „Non enim misit Deus Filium suum in mundum, ut iudicet mundum, sed ut salvetur mundus per ipsum", PSP 15/1, 193.

${ }^{20}$ Tamże.

${ }^{21}$ Tamże 16, 3, NBA 24/1, 382, PSP 15/1, 244.

${ }^{22}$ Por. tamże 17, 1, NBA 24/1. 390.

${ }^{23}$ Por. tamże 114, 3, NBA 24/2, 1514.

${ }^{24}$ Por. tamże 91, 3, NBA 24/2, 1302.
} 
że rozmnożyłeś miłosierdzie Twoje, Boże"25. Jakiekolwiek zdrowie ciała czy to u ludzi, czy też u niemych zwierząt pochodzi od Boga, to jednak - jak zauważa przy tej okazji Augustyn - istnieje pewien rodzaj zdrowia, ,które nie tylko nie jest wspólne dla ludzi i dla zwierząt, lecz nawet wspólne nie jest dla samych ludzi, dobrych i złych"26. Jest tu mowa oczywiście o duchowym zdrowiu, którym cieszyć się mogą ludzie dobrzy. Zdrowie to, udzielane w procesie leczenia przez Jezusa, ostateczne źródło posiada bez wątpienia w Bogu Ojcu, ponieważ wszystko, co posiada Syn, zostało udzielone Mu przez Ojca (J 17, $\left.7^{27}\right)$. Mając to na uwadze, Autor homilii z emfazą poucza swoich słuchaczy, że zdrowie ciała nie ma pierwszorzędnego znaczenia ${ }^{28}$, gdyż jego brak nie powoduje, że dusza przestaje być bezpieczna (tuta) ${ }^{29}$. Niekiedy nawet - jak zauważa Augustyn zdarza się, że brak fizycznego zdrowia powstrzymuje człowieka od duchowych chorób. W tym kontekście Autor homilii udziela następującego wyjaśnienia:

„Iluż w łóżku choruje, będąc bez winy, a czyż gdyby byli zdrowi, nie dopuściliby się występków? Czyż wielu zdrowie nie szkodzi? Czy nie o wiele lepiej byłoby dla rozbójnika, który wyrusza w drogę w celu zabicia człowieka, żeby zachorował? Czy nie byłoby lepiej temu, który wstaje w nocy, aby podkopać ścianę, żeby gorączka nim wstrząsnęła? Będąc chory - jest bardziej niewinny, mając zdrowie jest bardziej występny" ${ }^{\prime 30}$.

Jak podkreśla Augustyn, Jezus przychodząc na ziemię, stał się przede wszystkim lekarzem duchowej sfery człowieka. Dokonywane przez Niego cudowne uzdrowienia chorób fizycznych ostatecznie także służyły duchowemu dobru ludzi, gdyż w ten sposób Chrystus pragnął wzbudzić wiarę, która stanowi warunek konieczny, aby przyjąć Boży dar duchowego uzdrowienia ${ }^{31}$. Konieczność Jego przyjścia na ziemię, aby uleczyć człowieka, była spowodowana nieskutecznością Prawa ${ }^{32}$, danego przez Mojżesza. Prawo bowiem pełniąc rolę sługi, przygotowującego na przyjście lekarza, uświadamiało żyjącym pod Prawem potrzebę przybycia lekarza, który leczy przyniesioną przez Siebie łaską i prawdą ${ }^{33}$. Wyjaśniając tę kwestię, Augustyn przytacza w tym kontekście naukę Pawła Apostoła, zaczerpniętą z Ga 4, 4:

${ }^{25}$ Tamże 34, 3, NBA 24/1, 716: „Homines et iumenta salvos facies, Domine; sicut multiplicata est misericordia tua, Deus".

${ }^{26}$ Tamże 30, 3, NBA 24/1, 662-664, PSP 15/1, 405-406.

${ }^{27}$ Por. tamże 106, 1, NBA 24/2, 1434; także 106, 6, NBA 24/2, 1442.

${ }^{28}$ Por. tamże 32, 9, NBA 24/1, 698-700; także In Joannis Epistolam ad Parthos tractatus 10, 5, NBA 24/2, 1842.

${ }^{29}$ Por. In Joannis Epistolam ad Parthos tractatus 1, 9, NBA 24/2, 1652.

${ }^{30}$ In Joannis Evangelium tractatus 7, 12, NBA 24/1, 168-170, PSP 15/1, 122.

${ }^{31}$ Por. tamże 39, 3, NBA 24/1, 794.

32 Por. G.M. Baran, Uzdrowienia dokonane przez Jezusa - Boskiego lekarza $w$ świetle Augustynowych homilii do Ewangelii Jana Apostoła, TST 29 (2010) nr 1, 17-20.

${ }^{33}$ Por. tamże 3, 2, NBA 24/1, 44; akże 2, 16, NBA 24/1, 60. 
„[Bóg] zesłał Syna swego, zrodzonego z niewiasty i podległego Prawu, aby tych, którzy byli pod Prawem, odkupił, żebyśmy dostąpili przybrania za dzieci" ${ }^{34}$.

Przychodząc na świat, Chrystus stał się światłem, które oświeciło ciemności grzechu. Ludzie mający przeświadczenie o niewystarczalności Prawa, które nie było w stanie dać im uzdrowienia, szukali tego światła przy pomocy danej przez Boga lampy (lucerna), jaką był sam Jan Chrzciciel - posłany, aby wskazać na Światło, czyli Jezusa Chrystusa ${ }^{35}$. Dzięki światłu, jakim jest Chrystus, stało się możliwe uleczenie ludzi dotkniętych ślepotą ${ }^{36}$.

Jezus jako Boski lekarz doskonale znał stan zdrowia każdego człowieka. Przykładem tego może być trafność diagnozy, jaką postawił Natanaelowi już w chwili pierwszego spotkania ${ }^{37}$. Jak podkreśla Augustyn, przejawem Chrystusowej znajomości stanu ducha człowieka, było także przepowiedzenie Piotrowi potrójnego zaparcia się Mistrza. Piotr bowiem ,,będąc słabym, szczycił się swą wolą; ale lekarz przenika stan jego zdrowia" ${ }^{38}$. W tym kontekście Autor homilii w taki oto sposób poucza swoich słuchaczy:

„Albowiem swej słabości Piotr nie znał, gdy słyszał od Pana, iż trzykrotnie się go zaprze i będąc chory, siebie nie znał. Lekarz zaś znał chorego. Są więc takie rzeczy, o których Bóg wie, a o których my sami nie wiemy"39.

Jezus, jako prawdziwy Bóg i prawdziwy człowiek, zna zatem każdą duchową dolegliwość człowieka. $Z$ tej racji dobiera odpowiednie środki lecznicze (mordacia reparandae sanitati $)^{40}$, które przynoszą właściwy skutek dla chorego. Niekiedy są one dość ostre i nie zawsze rozumiane, a co za tym idzie, niechętnie przyjmowane przez człowieka. Odwołując się do praktyk lekarskich, Augustyn poucza zatem swoich słuchaczy:

„Na pewno lekarz spełni twe życzenie i da ci zimnej wody, jeśli ci pomoże, gdyby ci jednak miała zaszkodzić, odmówi ci jej. Czyż nie wysłuchuje cię dla twego zdrowia, choć się sprzeciwia twojej woli?"41

$\mathrm{Na}$ innym miejscu natomiast, Autor homilii wyjaśniając tę samą kwestię, zadaje retoryczne pytania, które same sugerują odpowiedź:

${ }^{34}$ Tamże 3, 2, NBA 24/1, 46: ,[Deus] misit Filium suum factum ex muliere, factum sub Lege, ut eos qui sub Lege erant, redimeret, ut adoptionem filiorum reciperemus", PSP 15/1, 52.

${ }^{35}$ Por. tamże 2, 8, NBA 24/1, 32-34.

${ }^{36}$ Por. tamże 1, 18-19, NBA 24/1, 22; 2, 8, NBA 24/1, 32-34; zob. także 18, 11 NBA 24/1, 428$430 ; 39,8$, NBA 24/1, 800 .

${ }^{37}$ Por. tamże 7, 18, NBA 24/1, 176.

${ }^{38}$ Tamże 66, 1, NBA 24/2, 1146, PSP 15/2, 127.

${ }^{39}$ Tamże 32, 5, NBA 24/1, 692, PSP 15/1, 421.

${ }^{40}$ Por. tamże 18, 11, NBA 24/1, 428.

${ }^{41}$ In Joannis Epistolam ad Parthos tractatus 6, 8, NBA 24/2, 1758, PSP 15/2, 448; por. także In Joannis Evangelium tractatus 73, 3, NBA 24/2, 1192. 
„Czy bolesny jęk operowanego powstrzymuje rękę dobrego lekarza? Ów woła, ten wycina. Czy okrutny jest ten, kto nie słyszy krzyczącego, czy raczej miłosierny, bo wycinając ranę, leczy chorego?"42

Na kanwie wykładu o stosowanych przez Boskiego lekarza - Jezusa Chrystusa środkach leczniczych Augustyn porusza także kwestię modlitwy, w której ludzie proszą o spełnienie się różnych rzeczy. W tym kontekście wyjaśnia, że Bóg nie zawsze wysłuchuje próśb proszącego Go człowieka, gdyż spełnienie niektórych z nich mogłoby przynieść nie tyle duchową korzyść, ile nieszczęście w postaci duchowej choroby ${ }^{43}$.

Zasadniczym środkiem leczniczym, dzięki któremu staje się możliwe duchowe uzdrowienie człowieka, jest - jak uczy Augustyn - łaska Boża ${ }^{44}$. Autor homilii wspomina nadto o innym jeszcze środku leczniczym, którym posługuje się Bóg: jest nim „karcenie” (correptio). Stosowane przez Boga karcenie, czy też - jak to miało miejsce w przypadku Pawła Apostoła - dopuszczony tak zwany „oścień dla ciała” (stimulus corporis), służy duchowemu umocnieniu, aby człowiek potrafił przezwyciężać pokusy szatana i trwał niezachwianie przy Chrystusie - Baranku ${ }^{45}$.

Nauczając o ostrych środkach leczniczych, Augustyn jednocześnie wzywa swoich słuchaczy, aby dla własnego dobra stosowali się do wskazań Jezusa - lekarza. W tym kontekście używa bardzo mocnego stwierdzenia: „Ten się gubi, kto przepisów lekarza nie chce przestrzegać" ${ }^{46}$. Z tej racji w czasie ziemskiej działalności Jezus poprzez swoje nauczanie oraz podejmowane dzieła starał się poruszyć wolę słuchaczy, aby zaczęli szukać Go jako lekarza ${ }^{47}$. To szukanie - jak zaznacza Augustyn - dokonuje się zawsze dzięki wierze:

„Nie biegniemy bowiem do Chrystusa nogami, lecz wiarą; przystępujemy do Niego nie ruchami ciała, lecz wolą serca"48.

Stąd też wiara, a także - jak uczy Autor homilii - nadzieja, jest obok pokornego uznania własnej choroby warunkiem nieodzownym do tego, aby zostać uleczonym $^{49}$.

${ }^{42}$ In Joannis Evangelium tractatus 7, 12, NBA 24/1, 170, PSP 15/1, 123.

${ }^{43}$ Por. In Joannis Epistolam ad Parthos tractatus 6, 8 NBA 24/2, 1758.

${ }^{44}$ Por. In Joannis Evangelium tractatus 7, 12, NBA 24/1, 170. Należy zauważyć, że Augustyn wszelkie przejawy działalności Bożej względem człowieka postrzega w kategoriach łaski, por. R. Kostecki, Nauka św. Augustyna o łasce, w: tenże, Tajemnica życia nadprzyrodzonego: zagadnienie łaski uświęcającej, Warszawa 1975, 525-545; a także W. Eborowicz, Św. Augustyn doktor łaski, AK 71 (1979) t. 92, nr 420, 430-438.

${ }^{45}$ Por. In Joannis Evangelium tractatus 7, 12, NBA 24/1, 170.

${ }^{46}$ Tamże 12, 12, NBA 24/1, 292, PSP 15/1, 193.

${ }^{47}$ Por. tamże 18, 1, NBA 24/1, 412.

${ }^{48}$ Tamże 26, 3, NBA 24/1, 596, PSP 15/1, 368.

${ }^{49}$ Por. tamże 39, 3, NBA 24/1, 794; zob. także In Joannis Epistolam ad Parthos tractatus 8, 13 , NBA 24/2, 1808. 
Jak podkreśla Augustyn, uleczenie człowieka, jakie dokonał własną, tak wielką mocą (tanta potestas) ${ }^{50} \mathrm{Chrystus}^{51}$, jest wyrazem Jego wielkiej wszechmocy (omnipotentia), gdyż ,wielkie były choroby, rany nie do uleczenia, beznadziejna niemoc", a jednak Jezus - lekarz dokonał uzdrowienia rodzaju ludzkiego ${ }^{52}$. W zdziałanych przez Jezusa Chrystusa uzdrowieniach zajaśniała również chwała Boża. Jako przykład tego Augustyn podaje uleczenie Pawła Apostoła, który z wielkiego prześladowcy Kościoła stał się gorliwym Apostołem Chrystusa ${ }^{53}$.

Dokonane przez Chrystusa uleczenia są nie tylko wyrazem Jego wszechmocy, lecz także Bożego dobrodziejstwa (beneficium) i miłosierdzia (misericordia $)^{54}$. Jezus, jako posłany przez Ojca Jednorodzony Syn Boży, przybył bowiem na ziemię pierwszorzędnie po to, aby leczyć, a nie sądzićs5. W tym przejawiła się wielka miłość Boga do grzesznych ludzi. Jak bowiem, podkreśla Autor homilii, „,[Bóg] umiłował chorych, by im przywrócić zdrowie" 56 i w tym celu w osobie Syna Bożego przybył do ludzi, którzy mieli zostać uzdrowieni z duchowej choroby ${ }^{57}$.

Chrystus jako Boski lekarz miłuje wszystkich chorych ludzi, jednakże jak uczy Augustyn - z nienawiścią odnosi się do tkwiącej w człowieku choroby $^{58}$. $\mathrm{Z}$ tej racji - jak to zostało już powiedziane - pragnie ją usunąc za wszelką cenę, nawet przy użyciu ostrych, to znaczy przykrych, dla człowieka, środków. Jezus, jako Wszechmocny Lekarz, uwalnia zatem człowieka od duchowych chorób i dolegliwości. Jest w stanie nie tylko leczyć, ale także wskrzeszać umarłych ${ }^{59}$. Ostatecznym celem uzdrowienia, jakiego pragnie dokonać Chrystus, jest uzdrowienie od śmierci wiecznej (a morte sempiterna) ${ }^{60}$, które może dotyczyć zarówno sfery duchowej, jak i cielesnej człowieka.

\section{JEZUS LEKARSTWEM}

W Augustynowym nauczaniu Jezus jest postrzegany nie tylko jako lekarz, który leczy zarówno fizyczne, jak i duchowe choroby, lecz także jako „samo

\footnotetext{
${ }^{50}$ Por. In Joannis Evangelium tractatus 91, 3, NBA 24/2, 1302.

${ }^{51}$ Por. tamże 31, 9, NBA 24/1, 680, gdzie Augustyn wyjaśnia, że nawet uzdrowienia dokonywane przez Piotra Apostoła, działy się mocą Chrystusa.

${ }_{52}$ Por. In Joannis Epistolam ad Parthos tractatus 8, 13, NBA 24/2, 1808, PSP 15/2, 475.

${ }^{53}$ Por. tamże 8, 2, NBA 24/2, 1790-1792.

${ }^{54}$ Por. In Joannis Evangelium tractatus 110, 6, NBA 24/2, 1478.

${ }^{55}$ Por. tamże 36, 4 NBA 24/1, 746-748.

${ }^{56}$ In Joannis Epistolam ad Parthos tractatus 9, 10, NBA 24/2, 1830, PSP 15/2, 487.

${ }^{57}$ Por. tamże 7, 7, NBA 24/2, 1780.

${ }^{58}$ Por. In Joannis Evangelium tractatus 41, 9, NBA 24/1, 832; zob. także 65, 2, NBA 24/2, 1142.

${ }^{59}$ Por. tamże 49, 21, NBA 24/1, 990.

${ }^{60}$ Por. tamże 3, 3, NBA 24/1, 46.
} 
zdrowie" (ipsa salus) ${ }^{61}$. Chrystus zatem jako lekarz, który w procesie uzdrawiania przywraca zdrowie, udziela niejako samego siebie.

Autor homilii określa także Jezusa mianem „lekarstwa” (medicamentum) ${ }^{62}$, czy też „lekarstwa pochodzącego z nieba" (medicina de coelo veniens) $)^{63}$. Jezus bowiem przychodząc na ziemię jako Boski lekarz leczył i nadal leczy chorych duchowo ludzi samym sobą: swoją osobą i nauczaniem, czyli głoszoną Ewangelią oraz całym dziełem zbawczym. W tym kontekście Augustyn, komentując słowa Ps 35, 9: „Będą upojeni obfitością domu Twego i strumieniem rozkoszy Twojej napoisz ich" ${ }^{64}$, stwierdza, że Jezus jest niejako leczniczym winem ${ }^{65}$, którym upicie jest chwalebne, ponieważ nie mąci umysłu, lecz nim kieruje. Ponadto upicie się tego rodzaju winem zapewnia na stałe zdrowie, nigdy natomiast go nie odbiera $^{66}$. Dlatego - jak poucza Autor homilii - czymś wskazanym dla człowieka jest czerpać z takiego źródła, jakim jest sam Chrystus, który o sobie samym jako o lekarstwie ${ }^{67}$, jako o winie, dającym zdrowie, powiedział: „Jeśli kto pragnie, niech przyjdzie do mnie" $(\mathrm{J} 7,37)^{68}$. Skoro wszyscy są chorzy duchowo, to również wszyscy powinni być spragnieni lekarstwa, którym jest sam Chrystus, wychodzący naprzeciw chorym jako zdrój życia (por. Ps 35,10$)^{69}$.

Jak zauważa Autor homilii, Jezus mógł stać się dla człowieka zarówno lekarzem, jak i lekarstwem, dzięki Wcieleniu oraz złożonej z siebie zbawczej Ofierze.

1. Rola Wcielenia Chrystusa w procesie duchowego leczenia. Analizując treść nauczania Augustyna, można zauważyć, że bardzo wielką rolę w historii dziejów zbawienia człowieka przypisuje on Wcieleniu Jezusa Chrystusa Jednorodzonego Syna Bożego ${ }^{70}$. Przez Jezusa - Słowo Boże dokonało się bowiem stworzenie człowieka, ponieważ „wszystko przez Nie się stało” (J 1, 3), przez Jezusa - Słowo Wcielone dokonało się natomiast odnowienie ludzkiej

\footnotetext{
${ }^{61}$ Por. tamże 30, 3, NBA 24/1, 662.

${ }^{62}$ Por. In Joannis Epistolam ad Parthos tractatus 8, 14, NBA 24/2, 1808.

${ }^{63}$ Por. In Joannis Evangelium tractatus 7, 2, NBA 24/1, 154-156.

${ }^{64}$ Tamże 34, 4, NBA 24/1, 718: „Ab ubertate domus tuae; et torrente voluptatis tuae potabis eos", PSP 15/1, 434.

${ }^{65}$ D. Forstner (Świat symboliki chrześcijańskiej, tłum. i oprac. W. Zakrzewska - P. Pachciarek - R. Turzyński, Warszawa 1990, 181) na podstawie analizy tekstów biblijnych zauważa, że wino w ST było symbolem życia, radości i zadowolenia (por. Syr 31, 27n; Prz 31, 6n.). Na starożytnym wschodzie natomiast wino było uważane za symbol młodości i wiecznego życia.

${ }^{66}$ Por. In Joannis Evangelium tractatus 34, 4, NBA 24/1, 716-718.

${ }^{67}$ Por. tamże 3, 6, NBA 24/1, 50.

${ }^{68}$ Tamże 34, 4, NBA 24/1, 718: „Qui sitit, veniat ad me”, PSP 15/1, 434.

${ }^{69}$ Por. tamże.

${ }^{70}$ Por. A. Eckmann, Przebóstwienie człowieka w pismach wczesnochrześcijańskich, Lublin 2003, 107; tenże, Incarnatio Christie w pismach św. Augustyna. Istota i cel, VoxP 20 (2000) t. 38-39, 237-445; G.M. Baran, Motyw „synostwa Bożego” w homiliach świętego Augustyna do Ewangelii oraz Pierwszego Listu św. Jana Apostoła, Tarnów 2010, 38-40.
} 
natury, która uległa skażeniu na skutek grzechu Adama ${ }^{71}$. Celem przyjęcia ludzkiej natury i przyjścia Jezusa na ziemię było zatem odnowienie człowieka, a dokładniej mówiąc, odnowienie zniekształconego w człowieku obrazu i podobieństwa Bożego ${ }^{72}$. To odnowienie w nauce Augustyna jest bez wątpienia tożsame z uzdrowieniem człowieka z duchowej choroby, gdyż zarówno odnowienie, jak i uzdrowienie wiąże się z oczyszczeniem ludzkiej natury z dziedziczonego po Adamie skażenia grzechem i uwolnieniem człowieka z jakiejkolwiek niewoli grzechu ${ }^{73}$.

Bez Wcielenia Słowa Bożego - Jednorodzonego Syna Bożego, niemożliwym byłoby odnowienie człowieka oraz jego uleczenie. Prawdę tę bardzo mocno akcentuje Autor homilii, kiedy stwierdza:

„Przez to, iż «Słowo stało się ciałem i zamieszkało między nami», stało się dla nas lekarstwem" 74 .

Chrystus zatem stał się lekarstwem dzięki przyjęciu ludzkiej natury. Innymi słowy mówiąc, Boska natura Chrystusa obleczona w człowieczeństwo stała się środkiem leczniczym dla ludzi, dotkniętych skażeniem grzechu. Dzięki temu bowiem, że Syn Boży równy w Bóstwie Bogu-Ojcu ${ }^{75}$ przyjął ludzką naturę $^{76}$, ludzie mogli ujrzeć Bożą chwałę i poznać Ojca, który jest w niebie ${ }^{77}$.

Ucząc o roli Wcielenia w procesie uzdrowienia człowieka $\mathrm{z}$ duchowej choroby, Augustyn posługuje się metaforą, poprzez którą wyjaśnia, że w pełni uniżenia przyjęta przez Chrystusa ludzka natura jest niejako „maścią na oczy”. Tego rodzaju maść stanowi środek leczniczy oczu serca, czyli duchowych oczu. Autor homilii uczy bowiem, że oczy serca zostały zranione przez proch (pulvis), czy też ziemię (terra), która oślepiła w duchowy sposób człowieka ${ }^{78}$. Mówiąc o prochu i o ziemi, które ranią duchowe oczy, Augustyn ma na myśli ciało człowieka ${ }^{79} . \mathrm{Z}$ tej racji w ten sposób naucza:

„A więc ciało cię oślepiło [...]. Dusza bowiem, przyzwalając na uczucia cielesne, cielesną się stała; to sprawiło, iż oko serca oślepło"80.

${ }^{71}$ Por. In Joannis Evangelium tractatus 1, 12 NBA 24/1, 14; także 2, 15 NBA 24/1, 40.

${ }^{72}$ Por. tamże 18, 10, NBA 24/1; także 8, 2 NBA 24/1, 190. Na temat człowieka jako ,imago Dei” w nauce Augustyna por. M. Jędrychowski, Poznać Boga i człowieka, Poznań 2007, 45-53; S. Kowalczyk, Człowiek i Bóg w nauce św. Augustyna, Lublin 2007, 87.

${ }^{73}$ Por. In Joannis Evangelium tractatus 10, 11, NBA 24/1, 248; także 12, $12-13$ NBA 24/1, 292-294.

${ }^{74}$ Tamże 3, 6, NBA 24/1, 50, PSP 15/1, 56.

${ }^{75}$ Por. np. tamże 29, 8, NBA 24/1, 658.

${ }^{76} \mathrm{Na}$ temat dwóch natur w osobie Jezusa Chrystusa por. S. Pieszczoch, Charakterystyka chrystologii św. Augustyna, VoxP 8 (1988) t. 14, 192-193.

${ }^{77}$ Por. In Joannis Evangelium tractatus 3, 6, NBA 24/1, 52; także 14, 12 NBA 24/1, 342.

${ }^{78}$ Por. tamże 2, 16, NBA 24/1, 40.

${ }^{79}$ Por. Forstner, Świat symboliki chrześcijańskie, s. 79-80.

${ }^{80}$ In Joannis Evangelium tractatus 2, 16, NBA 24/1, 42, PSP 15/1, 51. 
Postrzeganie przez Autora homilii ciała ludzkiego jako prochu, czy też jako ziemi, jest z pewnością - chociaż nie mówi o tym wprost - nawiązaniem do opisu stworzenia, gdzie jest mowa o tym, iż człowiek został przez Boga stworzony z prochu ziemi (Rdz 2, 7). Terminy „proch” oraz „ziemia” są zatem dla Augustyna metaforą ludzkiej natury. Ostatecznie jednak prochem, który spowodował duchową ślepotę, są grzechy i nieprawości człowieka ${ }^{81}$.

Ulegając ciału, człowiek potrzebował - jak zaznacza Autor homilii - uzdrowienia również poprzez ciało, które jednak nie było obciążone zepsuciem ${ }^{82}$. Dlatego Chrystus przyjął ludzka naturę, aby skoro „proch” oślepił człowieka, „proch” go również uzdrowił. Uzdrawiający człowieka ,proch”, czyli ciało, to nic innego jak człowieczeństwo Chrystusa, które Augustyn określa mianem „lekarstwa” (medicamentum), będącego swego rodzaju „maścią na oczy” $(\text { collyrium })^{83}$.

Uzdrowienie człowieka z duchowych dolegliwości stało się zatem możliwe dzięki Wcieleniu Słowa Bożego. W metaforyczny sposób fakt Wcielenia Augustyn opisuje za pomocą zaczerpniętej z Ps 84, 12 frazy: „Veritas de terra orta est” - „Prawda z ziemi wyrosła”. Wyjaśniając znaczenie proroctwa przytoczonych słów, Autor homilii stwierdza, że Jezus, będący samą prawdą (ipsa Veritas), przyoblókł się w ciało poprzez zrodzenie z Maryi Dziewicy, z której chociaż bez udziału ziemskiego ojca ${ }^{84} \mathrm{w}$ rzeczywisty sposób się narodził ${ }^{85}$. Dzięki temu człowiek może być wyzwolony z niewoli grzechu ${ }^{86}$. Uwolniony od choroby grzechu staje się $\mathrm{z}$ duchowo chorego człowiekiem zdrowym ${ }^{87}$. Jego oczy, uwolnione od obciążenia grzechem, nabywają w ten sposób zdolności pojmowania światła, którym jest Jezus ${ }^{88}$.

Dzięki przyjęciu ludzkiej natury przez Chrystusa, możliwym dla człowieka stało się oglądanie chwały, jaką Jednorodzony Syn Boży, pełen łaski i prawdy, otrzymuje od Ojca ${ }^{89}$. Jezus Chrystus, równy w bóstwie Bogu Ojcu, poprzez stanie się człowiekiem sprawił również, że człowiek przez wiarę mógł pojąć samego Boga. $Z$ tej racji Autor homilii poucza:

„Stał się On [Chrystus] człowiekiem dla cielesnego oka, abyś przez wiarę w Tego, który cieleśnie mógł być widzialny, został uzdrowiony, żebyś widział Tego, którego duchowo widzieć nie mogłeš" ${ }^{\circ}$.

\footnotetext{
${ }^{81}$ Por. tamże 1, 19, NBA 24/1, 22.

${ }^{82}$ Por. tamże 36, 2, NBA 24/1, 742-744; także 4, 10 NBA 24/1, 80-82.

${ }^{83}$ Por. tamże 2, 16, NBA 24/1, 42.

${ }^{84}$ Por. tamże 14, 2, NBA 24/1, 326; 26, 10, NBA 24/1, 604; 27, 4, NBA 24/1, 620-622; 33, 2 , NBA 24/1, 704; 36, 2, NBA 24/1, 742-744; 50, 13, NBA 24/1, 1010.

${ }^{85}$ Por. tamże 41, 1, NBA 24/2, 1014.

${ }^{86}$ Por. tamże 41, 4, NBA 24/2, 1016.

${ }^{87}$ Por. tamże 41, 1, NBA 24/2, 1014.

${ }^{88}$ Por. tamże 1, 19, NBA 24/1, 12.

${ }^{89}$ Por. tamże 3, 6, NBA 24/1, 52.

${ }^{90}$ Tamże 14, 12, NBA 24/1, 342, PSP 15/1, 222.
} 
Człowieczeństwo Jezusa stało się zatem niejako drogą, którą człowiek może dotrzeć do bóstwa Chrystusa ${ }^{91}$. Można więc wysunąć wniosek, że w owej maści na oczy - leczącej duchową ślepotę - którą było człowieczeństwo Chrystusa, istotny element stanowiło Jego bóstwo; ukryte w człowieczeństwie bóstwo Chrystusa jest źródłem mocy i łaski, dokonującej duchowego uzdrowienia.

2.Znaczenie Ofiary Krzyża w procesie duchowego leczenia. Podkreślając rolę Wcielenia Chrystusa w procesie leczenia człowieka z duchowej choroby, Augustyn zwraca także uwagę na kwestię zbawczego wymiaru męki i śmierci Jezusa. W tym kontekście poucza swoich wiernych w następujący sposób:

„Jaki lekarz? Nasz Pan Jezus Chrystus. Jaki Pan nasz Jezus Chrystus? Ten, którego widzieli ci, którzy Go ukrzyżowali. Schwytanego policzkowano, biczowano, opluto, cierniem ukoronowano, na krzyżu zawieszono, gdzie umarł; włócznią Go zraniono, zdjęto z krzyża, w grobie złożono. Ten jest Pan nasz Jezus Chrystus: jest nim zaiste. Jest On cały lekarzem ran naszych. [...] Jest On cały naszym lekarzem, jest nim rzeczywiście. [...] Tam uleczył twoje rany, gdzie sam swoje długo znosił; tam cię od śmierci wiecznej uzdrowił, gdzie On do czasu umrzeć raczył"92.

A zatem - w świetle przytoczonej wypowiedzi - uzdrowienie człowieka przez Jezusa-lekarza dokonuje się także dzięki Jego męce oraz śmierci. Jednakże - jak zauważa Autor homilii - aby mogła dokonać się zbdawcza ofiara Chrystusa, wcześniej musiało Słowo stać się ciałem. Jezus jako lekarz, aby dokonać uzdrowienia człowieka, przyszedł zatem na ziemię w ciele, aby „W ciele występki ciała wyniszczyć i śmiercią (swoją) śmierć zabić" ${ }^{93}$. Można więc powiedzieć, że jak w Adamie wszyscy zgrzeszyli i stali się w duchowy sposób chorzy, tak w Chrystusie wszyscy doznają uzdrowienia. Chrystus przyjmując bowiem ludzkie ciało stał się nowym Adamem, który reprezentuje całą ludzkośśc ${ }^{4}$. W jego ludzkiej naturze dokonało się przez podjętą śmierć uzdrowienie skażonej grzechem natury każdego człowieka.

\footnotetext{
${ }^{91}$ Por. tamże 42, 8, NBA 24/2, 1036.

92 Tamże 3, 3, NBA 24/1, 46, PSP 15/1, 53.

${ }_{93}$ Por. tamże 2, 16, NBA 24/1, 42.

94 Jak uczy Augustyn, Jezus jest nowym, czyli drugim Adamem, którego figurą był pierwszy Adam
} (por. tamże 15, 8, NBA 24/1, 352). Jezus bowiem stając się człowiekiem przyjął ciało z Maryi - ziemskiej matki, która jak każdy człowiek pochodziła od Adama (por. tamże 10, 12, NBA 24/1, 248-250). Prawdę tę Augustyn ilustruje alegorycznym tłumaczeniem liczby lat budowy świątyni Jerozolimskiej, kiedy objaśnia wersety J 2, 19-20: ,Solvite templum hoc, et in tribus diebus excitabo illud. Dixerunt ergo Iudaei: «Quadraginta et sex annis aedificatum est templum hoc, et tu dicis: In tribus diebus excitabo illud?»". Jak dodaje Autor biblijny, Jezusowi chodziło o świątynię Jego ciała (por. tamże 10, 10, BNA 24/1, 246). Augustyn wyjaśniając tę kwestię, poucza swoich słuchaczy, że owa świątynia Jezusowego ciała pochodzi od Adama, o czym świadczy przytoczona w IV Ewangelii liczba lat budowy jerozolimskiej świątyni - czterdzieści sześć. W liczbie tej - zdaniem Autora homilii - wyraża się bowiem imię Adama. Podstawą takiej interpretacji jest grecki system oznaczania liczb za pomocą liter alfabetu. 
Wyjaśnienie, dotyczące leczącej roli Chrystusowej ofiary krzyża, Augustyn zasadniczo opiera na zaczerpniętym z IV Ewangelii tekście: „Jak Mojżesz podwyższył węża na pustyni, tak musi być podwyższony Syn Człowieczy, aby każdy, kto weń wierzy, nie zginął, ale miał życie wieczne (J 3, 14) ${ }^{95}$. Komentując przytoczony fragment Ewangelii, w ten oto sposób poucza swoich słuchaczy:

„Tymczasem teraz, bracia, spoglądajmy na ukrzyżowanego Chrystusa, abyśmy z grzechu zostali uleczeni [...]. Jak ci, którzy spoglądali na owego węża, nie zginęli z powodu ukąszeń węża, tak i ci, którzy z wiarą patrzą na śmierć Chrystusa, są uzdrowieni z ukąszeń grzechów. Lecz tamci byli ocaleni od śmierci dla doczesnego życia, Ten zaś mówi, «aby mieli życie wieczne». Taka bowiem jest różnica między obrazem a rzeczą samą; obraz przedstawiał życie doczesne, a sama rzecz, której tamten był figurą, użycza wiecznego życia" ${ }^{\prime 9}$.

W dalszym ciągu tej samej homilii Augustyn wyjaśnia:

„Pan bowiem znalazł wszystkich jako grzeszników i wszystkich z grzechów uzdrawia, i ów wąż, w którym jest wyobrażona śmierć Pana, uzdrawia ukąszonych. Z powodu ukąszeń węża został wąż wywyższony, tj. śmierć, jaką Pan podjął za śmiertelnych ludzi, których znalazł jako niesprawiedliwych"97.

Jak widać w świetle przytoczonej wypowiedzi Autora homilii, śmierć Chrystusa uzdrawia z ukąszeń grzechów. Jest ona zatem niejako lekarstwem, dzięki któremu dokonuje się uzdrowienie człowieka z duchowych dolegliwości.

Podobnie jak bez Wcielenia Chrystusa nie mogłoby się dokonać uzdrowienie człowieka, tak również niemożliwe byłoby ono bez podjętej przez Jezusa na krzyżu zbawczej śmierci, poprzez którą - jak poucza Augustyn - zostało wyeksponowane Boże miłosierdzie. Człowiek bowiem, który z własnej winy duchowo zachorował, nie mógł inaczej wyzdrowieć, jak tylko przez śmierć swojego lekarza ${ }^{98}$. Rany w naturze człowieka, spowodowane grzechami, zostały uzdrowione ranami Chrystusa ${ }^{99}$.

Kiedy zatem weźmie się pod uwagę liczbowe odpowiedniki kolejnych liter greckiej transkrypcji imienia Adam, czyli: $\alpha$ - alpha oznaczającą jeden; $\delta$ - delta oznaczającą cztery; $\alpha$ - alpha, czyli kolejny raz jeden; $\mu$ - mi oznaczające czterdzieści, można otrzymać jako ich sumę wynik czterdzieści sześć (por. tamże 10, 12, NBA 24/1, 248-250). Budowana więc w ciągu czterdziestu sześciu lat świątynia jest symbolem ciała, które Jezus - Syn Boży przyjął przez Maryję od Adama, a przez to stał się drugim nowym Adamem, reprezentującym całą ludzkość, por. Baran, Motyw ,synostwa Bożego”, s. 49-50.

${ }^{95}$ In Joannis Evangelium tractatus 12, 11, NBA 24/1, 290: „Sicut Moyses exaltavit serpentem in eremo, ita exaltari oportet Filium hominis; ut omnis qui credit in eum, non pereat, sed habeat vitam aeternam", PSP 15/1, 192.

${ }^{96}$ Tamże.

${ }^{97}$ Tamże 12, 13, NBA 24/1, 292, PSP 15/1, 193.

${ }^{98}$ Por. tamże 110, 7, NBA 24/2, 1480.

${ }^{99}$ Por. tamże 3, 3, NBA 24/1, 46; także 121, 4, NBA 24/2, 1576. 
III. SAKRAMENTY PRZESTRZENIĄ DZIAŁANIA JEZUSA-LEKARZA

Wskutek dziedziczenia po Adamie skażonej grzechem natury, a także z powodu popełnianych osobiście grzechów, człowiek jest dotknięty duchową chorobą. $Z$ tej choroby nie było w stanie uwolnić go Prawo Starego Przymierza. Tym, który dopiero tego dokonał, jest Jezus - Boski lekarz i lekarstwo z nieba. W tym celu przyjął ludzką naturę, aby własnym człowieczeństwem, dzięki któremu możliwym stało się dokonanie ofiary krzyża, uleczyć człowieka z duchowej choroby. Jezus zatem stał się Barankiem Bożym, który zgładził grzech świata (por. J 1, 29), gdyż tylko Jego krwią - jak podkreśla Augustyn - ludzie mogli być odkupieni ${ }^{100}$. Dzięki zabitemu Barankowi rodzaj ludzki został wyzwolony spod panowania diabła ${ }^{101}$, w którego niewoli znajdował się człowiek jako niewolnik grzechu ${ }^{102}$.

Istotą uleczenia, jakiego dokonał Chrystus przychodząc na ziemię, było zatem wyzwolenie człowieka z niewoli grzechu. Augustyn wyraźnie o tym poucza, stwierdzając:

„Na to bowiem przyszedł Chrystus jako człowiek, aby uwolnić ludzi od grzechów. «Na to objawił się Syn Boży, aby zniweczyć dzieła diabła»"103.

Szczególnym obszarem działania Jezusa jako lekarza leczącego, czyliuwalniającego od duchowych chorób - grzechów, są sakramenty. Pierwszorzędnie takim sakramentem jest ustanowiony przez Chrystusa chrzest, który Autor homilii nazywa Boskim sakramentem ${ }^{104}$. Mówiąc o jego skutkach, Augustyn w taki oto sposób naucza:

„Wierząc w Niego, przez odradzającą kąpiel [chrztu] otrzymawszy przebaczenie winy wszystkich grzechów, a mianowicie pierworodnego, który urodzenie sprowadza, i przeciw któremu odrodzenie szczególniej jest ustanowione, i innych, jakie popełniło się źle postępując, od wiecznego potępienia są uwolnienie $[\ldots]]^{\prime \prime 105}$.

Przez odradzającą kąpiel (lavacrum regenerationis), która niewątpliwie oznacza sakrament chrztu ${ }^{106}$, dokonuje się uwolnienie człowieka zarówno od grze-

${ }^{100}$ Por. tamże 7, 5, NBA 24/1, 158.

${ }^{101}$ Por. tamże 7, 6, NBA 24/1, 160.

${ }^{102}$ Por. tamże 41, 8, NBA 24/1 830.

${ }^{103}$ In Joannis Epistolam ad Parthos tractatus 4, 11, NBA 24/2, 1724, PSP 15/2, 429; także In Joannis Evangelium tractatus 2, 13, NBA 24/1, 38.

${ }^{104}$ Por. In Joannis Evangelium tractatus 5, 6, NBA 24/1, 98; 6, 21, NBA 24/1, 146; także In Joannis Epistolam ad Parthos tractatus 5, 6, NBA 24/2, 1734.

${ }^{105}$ In Joannis Evangelium tractatus 124, 5, NBA 24/2, 1616, PSP 15/2, 373.

${ }^{106}$ Por. tamże 56, 5, NBA 24/2, 1084; także 15, 4, NBA 24/1, 348. Augustyn paralelnie używa wyrażenia „lavacrum regenerationis” z wyrażeniem „lavacrum aquae in verbo”, które wprost utożsamia z sakramentem chrztu. 
chu pierworodnego (originale peccatum; reatus originalis), dziedziczonego po Adamie, jak i od wszystkich innych grzechów, popełnionych przez człowieka po chrzcie. Mając na uwadze fakt, że chrzest jako „odrodzenie z wody i Ducha" (por. J 3, 5) ${ }^{107}$ odpuszcza wszystkie grzechy, Autor homilii w wielu miejscach swego nauczania nie wyszczególnia, jakie grzechy są odpuszczane mocą tegoż sakramentu. Pojawia się natomiast ogólne stwierdzenie, że sakrament chrztu, określany w tym kontekście przez Autora homilii również paralelnymi wyrażeniami, oczyszcza ze wszystkich grzechów (omnia peccata) ${ }^{108}$.

Człowiek, który rodzi się z Adama jako grzesznik obciążony grzechem, dzięki Chrystusowi staje się usprawiedliwiony (iustificatus) i sprawiedliwy (iustus $)^{109}$. Usprawiedliwienie człowieka zatem i uczynienie go sprawiedliwym wydaje się być dla Autora homilii tożsame z odpuszczeniem grzechów. Bardzo wymownie w tym względzie brzmią następujące słowa Augustynowego pouczenia:

„Otrzymaliśmy łaskę z pełności Jego [Chrystusowego] miłosierdzia i obfitości Jego dobroci. Co otrzymaliśmy? Odpuszczenie grzechów, abyśmy przez wiarę byli usprawiedliwionymi”"110.

Potwierdzeniem tezy, że pomiędzy odpuszczeniem grzechów, a usprawiedliwieniem zachodzi tożsamość, może być Augustynowe nauczanie, zawarte w komentarzu do I Listu Jana Apostoła, gdzie występuje następujące stwierdzenie:

„Umiłował grzeszników, aby ich uświęcić; umiłował niesprawiedliwych, aby ich sprawiedliwymi uczynić; umiłował chorych, by im przywrócić zdrowie" $" 111$.

Analizując przytoczone zdanie, możemy zauważyć, że zawiera ono trzy paralelne zestawienia antytetycznych określeń: ,impios” - „pios”; ,iniustos” - „iustos”; ,aegros” - „,sanos”. Mając natomiast na uwadze to, że w nauczaniu Augustyna przymiotnik „chory” (aeger) jest metaforycznym określeniem człowieka dotkniętego grzechem, można stwierdzić, iż dla Augustyna być grzesznikiem oznacza to samo, co być niesprawiedliwym. Ten zaś, kto został uzdrowiony z choroby grzechu, czyli inaczej mówiąc, zostały mu odpuszczone grzechy, stał się w duchowy sposób zdrowym (sanus), to znaczy sprawiedliwym (iustus) $)^{112}$.

${ }^{107}$ Por. tamże 11, 1,NBA 24/1, 252; także 15, 4, NBA 24/1, 348.

${ }^{108}$ Por. In Joannis Epistolam ad Parthos tractatus 1, 5, NBA 24/2, 1646; 5, 6, NBA 24/2, 1734; także In Joannis Evangelium tractatus 11, 1, NBA 24/1, 252; In Joannis Epistolam ad Parthos tractatus 2, 4, NBA 24/2, 1672, gdzie pojawia się samo wyrażenie ,peccata”.

${ }^{109}$ Por. In Joannis Evangelium tractatus 3, 12, NBA 24/1, 58.

${ }^{110}$ Tamże 3, 10, NBA 24/1, 56, PSP 15/1, 58.

${ }^{111}$ In Joannis Epistolam ad Parthos tractatus 9, 10, NBA 24/2, 1830, PSP 15/2, 487.

${ }^{112}$ Por. Baran, Motyw „synostwa Bożego”, s. 148. 
Augustyn, ucząc na temat sakramentu chrztu, wyjaśnia także, że wiedza religijna, jaką nabył człowiek, a także dobre życie moralne, połaczone z realizacją uczynków miłosierdzia i praktyk ascetycznych, same w sobie nie mają mocy odpuszczenia grzechów. Autor homilii poucza o tym przede wszystkim katechumenów, ponieważ w jego czasach - jak sugeruje nauczanie analizowanych homilii - istniał prawdopodobnie poważny problem powstrzymywania się od przyjmowania chrztu przez pewną grupę katechumenów, którzy swoją wyższość moralno-duchową $\mathrm{w}$ stosunku do chrześcijan upatrywali $\mathrm{w}$ posiadanej wiedzy religijnej oraz praktykach religijnych, realizowanych na co dzień. W tym kontekście Augustyn kieruje do swoich słuchaczy następujące pouczenie:

„Zdarza się bowiem, iż widzisz katechumena, wstrzymującego się od wszelkiego płciowego pożycia, żegnającego się ze światem, wyrzekającego się wszystkiego, co posiadał i rozdzielającego to ubogim. Jest katechumenem. Może zna zbawienną naukę [wiary] lepiej, niż wielu wiernych. Powstaje obawa, aby sobie nie postawił pytania odnośnie chrztu świętego, który grzechy odpuszcza: co jeszcze więcej otrzymam? Oto jestem lepszy od tego lub tamtego wierzącego. Myśląc o wiernych, którzy żyją w związkach małżeńskich lub może nie znających nauki, mających i posiadających swe rzeczy, które on już sam rozdał ubogim, uważa, że jest lepszy od tego, który już jest ochrzczony, wówczas lekceważy sobie przystąpienie do chrztu. [...] I stawia sobie przed oczami tych, którymi gardzi i jakby uważał za ujmę dla siebie otrzymać to, co otrzymali od niego niżsi, bo mu się wydaje, iż jest lepszym, a jednak ma on wszystkie grzechy i jeśli nie przystąpi do zbawiennego chrztu, który od grzechów uwalnia, to z całą swą doskonałością nie może wejść do niebiańskiego Królestwa" ${ }^{113}$.

Z przytoczonych słów wynika wyraźnie, że przyjęcie chrztu jest warunkiem koniecznym ${ }^{114}$, aby zostały odpuszczone człowiekowi grzechy, czyli - innymi słowy mówiąc - aby człowiek został duchowo uzdrowiony.

Duchowe uzdrowienie człowieka, czyli odpuszczenie grzechów dokonuje się także w sakramencie pokuty. Chociaż Augustyn nie mówi o tym wprost w homiliach do pism Janowych, to jednak z kontekstu nauczania można wywnioskować, że kiedy naucza o odpuszceniu grzechów, które człowiek w wyniku złego postępowania (male agendo $)^{115}$ popełnił od chwili przyjęcia chrztu, ma na uwadze właśnie ten sakrament ${ }^{116}$.

Ucząc o sakramentach, jako przestrzeni działania Jezusa lekarza, który poprzez odpuszczenie grzechów leczy duchowe dolegliwości człowieka, Augustyn jednocześnie uświadamia swoim słuchaczom, że w pełni owocne

${ }^{113}$ In Joannis Evangelium tractatus 4, 13, NBA 24/1, 84, PSP 15/1, 74-75; także 5, 8, NBA 24/1, 102; 13, 6, NBA 24/1, 306.

${ }^{114}$ Por. tamże 38, 6, NBA 24/1, 782.

${ }_{115}$ Por. tamże 124, 5, NBA 24/2, 1616.

${ }^{116}$ Por. tamże 56, 5 NBA, 24/2, 1084; 57, 1, NBA 24/2, 1086; także 124, 5, NBA 24/2, 1616. 
przyjmowanie sakramentów ma miejsce we wspólnocie Kościoła. Tę kwestię Autor homilii wyjaśnia przede wszystkim odnośnie sakramentu chrztu. Przyjęty bowiem chrzest Chrystusa, całkowiecie bez łączności z Kościołem, chociaż jest ważny, to jednak - jak podkreśla Augustyn - nie może pomóc ${ }^{117}$. Sakrament ten, aby mógł być pożyteczny dla zbawienia (ad salutem) tego, który go przyjmuje, powinien być „posiadany” nie na „zewnątrz”, ale „wewnątrz” wspólnoty Kościoła. Na zewnątrz bowiem „posiadanie” sakramentu chrztu prowadzi do zguby (ad perniciem) $)^{118}$.

Wyjaśniając powyższą kwestię, Augustyn stwierdza, że chrzest „posiadany" poza Kościołem, nie tylko w niczym nie pomaga, ale nadto szkodzi. W tym kontekście podaje następująca tezę:

„I to, co święte może zaszkodzić; dobrym rzeczy święte są na zbawienie, złym na sąd" 119 .

Jako argument biblijny Autor homilii przywołuje nauczanie Pawła Apostoła z 1Kor 11, 29 na temat Eucharystii: „Kto zaś pożywa i pije niegodnie, sąd dla siebie pożywa i pije" ${ }^{120}$. Jak zatem niegodne przyjmowanie Eucharystii sprowadza na przyjmującego sąd, czyli karę ${ }^{121}$, tak również chrzest, chociaż sam w sobie jest święty, sprowadza karę na przyjmującego ten sakrament poza Kościołem.

W pełni owocne przyjmowanie chrztu, a co z tego wynika, skuteczne uzdrowienie duchowe - w świetle nauki Augustyna - można osiągnąć tylko we wspólnocie Kościoła. Z tej racji Autor homilii, posługując się metaforą, w dalszym ciągu naucza $\mathrm{w}$ ten sposób: „Lekarz nie dałby trucizny. Lekarz zdrowia udziela [...]"122. Jezus jako lekarz, działając w sakramentach, poprzez które odpuszcza grzechy, udziela zawsze duchowego zdrowia. Sakramenty przyjmowane natomiast niegodnie, poza wspólnotą Kościoła, stają się wówczas niejako trucizną, która zamiast zdrowia duchowego sprowadza na człowieka zgubę. Z tej racji Augustyn, mając na uwadze przypowieść o miłosiernym Samarytaninie (Łk 10, 30-37), wzywa swoich słuchaczy, aby w przypadku duchowej choroby prosili lekarza o zdrowie i pozwolili się zanieść do gospody jak ów podróżujący, który w czasie węrówki z Jerozolimy do Jerycha został dotkliwie poraniony przez zbójców. W tym kontekście Autor homilii, interpretując metaforycznie wspomnianą przypowieść, poucza, że lekarzem jest Chrystus, natomiast gospoda jest symbolem Kościoła, w którym poraniony grzechem człowiek może prawdziwie zostać uleczonym ${ }^{123}$.

\footnotetext{
${ }_{117}$ Por. tamże 6, 13, NBA 24/1, 136.

${ }^{118}$ Por. tamże 6, 14, NBA 24/1, 138.

${ }^{119}$ In Joannis Evangelium tractatus 6, 15, NBA 24/1, 138, PSP 15/1, 105.

${ }^{120}$ Tamże: „Qui autem manducat et bibit indigne, iudicium sibi manducat et bibit”.

${ }^{121}$ Por. tamże 22, 5, NBA 24/1, 516.

122 Tamże 6, 15, NBA 24/1, 138, PSP 15/1, 105.

${ }^{123}$ Por. tamże 41, 13, NBA 24/1, 838.
} 


\section{PEŁNIA UZDROWIENIA}

Człowiek poprzez zrodzenie z ziemskich rodziców, dziedziczy po Adamie skażoną naturę. Skażenie to dotyczy zarówno sfery duchowej, jak i fizycznej, gdyż i dusza, i ciało naznaczone są śmiercią ${ }^{124}$. Śmiercią zaś duszy jest grzech $^{125}$, który w nauczaniu Autora homilii jawi się jako duchowa choroba człowieka. Nie pozbawione jest chorób również i ciało w ziemskim życiu, u kresu którego obumiera w naturalny sposób, kiedy opuszcza je dusza ${ }^{126}$. Przychodząc na ziemię, Jezus - jak uczy Augustyn - stał się lekarzem ciał i dusz ludzkich ${ }^{127}$, lecząc zarówno choroby fizyczne, jak i duchowe, czyli grzechy. Analiza nauczania Autora homilii pozwala zauważyć, że daje on priorytet duchowemu uzdrowieniu, twierdząc, że zdrowie fizyczne niewiele znaczy W porównaniu ze zdrowiem duchowym. W tym kontekście tak oto poucza swoich słuchaczy:

„Bo czymże jest zdrowie, które ze śmiercią ginie, osłabione chorobą, nędzne, śmiertelne, przemijające. Troszcz się o nie tyle, aby ci choroba nie przeszkodziła w pełnieniu dobrych uczynków"128.

W ziemskiej perspektywie zdrowie ciała nie stanowi zasadniczej wartości dla Augustyna. Autor homilii ma jednak świadomość, że pełne szczęście w wieczności nastąpi wówczas, kiedy cały człowiek, wraz z duszą i zmartwychwstałym ciałem, które przestanie być obciążone słabościami, będzie przybywał w domu Ojca w królestwie niebieskim. Tę prawdę w następujący sposób wyjaśnia swoim słuchaczom:

„Gdy wyzwolimy się z wszelkich więzów śmiertelności, gdy przeminą czasy próby, gdy przepłynie rzeka tego świata i odzyskamy ową pierwszą szatę, ową nieśmiertelność, którą straciliśmy przez grzech, gdy to skazitelne przyoblecze nieskazitelność, to znaczy to ciało przywdzieje nieskazitelność i śmiertelne to ciało przyoblecze nieśmiertelność. Wtedy całe stworzenie pozna $\mathrm{w}$ nas doskonałe dzieci Boże tam, gdzie nie trzeba wystawiać się na próbę ani biczować, gdzie wszystko będzie poddane nam, a my Bogu"129.

To wszystko oczywiście nastąpi po zmartwychwstaniu wszystkich ludzi, które - jak podkreśla Augustyn - w stosunku do Chrystusowego zostało „odroczone do końca wieków"130.

\footnotetext{
${ }^{124}$ Por. np. tamże 14, 12, NBA 24/1, 342.

${ }^{125}$ Por. tamże 49, 3, NBA 24/1, 970.

${ }^{126}$ Por. tamże 47, 8, NBA 24/1, 940.

${ }^{127}$ Por. tamże 17, 1, NBA 24/1, 390.

${ }^{128}$ In Joannis Epistolam ad Parthos tractatus 10, 5, NBA 24/2, 1842, PSP 15/2, 495.

${ }_{129}$ Tamże 8, 7, NBA 24/1, 198, PSP 15/2, 470; także In Joannis Evangelium tractatus 86, 1 , NBA 24/2, 1270-1272; In Joannis Epistolam ad Parthos tractatus 8, 13, NBA 24/2, 1808.

${ }^{130}$ In Joannis Evangelium tractatus 64, 1, NBA 24/1, 1134, PSP 15/2, 120-121.
} 
Jak wynika z przytoczonego wyżej tekstu pełnia szczęścia nastąpi wówczas, kiedy zarówno dusza, jak i ciało zostaną całkowicie uzdrowione z jakiejkolwiek choroby. W tym kontekście można mówić o uzdrowieniu ze śmierci wiecznej ${ }^{131}$ tak duszy, jak i ciała. Uzdrowienie duszy zaczyna się realizować już w ziemskim wymiarze, kiedy to człowiek poprzez wiarę poddaje się procesowi leczenia, którego dokonuje Jezus - lekarz w rzeczywistości sakramentów. Ciało natomiast ostatecznie zostanie wyzwolone, czyli uzdrowione z wszelkich słabości w momencie zmartwychwstania. Dokona się to na wzór zmartwychwstania Jezusa, w którego ciele, jako ciele nowego Adama, zawarta jest cała ludzkość ${ }^{132}$. Jak bowiem Chrystus po swoim zmartwychwstaniu posiadał ciało pozbawione wszelkich słabości, chociaż przez czterdzieści dni ukazywał się jeszcze na ziemi Apostołom ${ }^{133}$, tak ciało każdego człowieka zostanie wyzwolone z obciążających je słabości, kiedy osiągnie przyszłą nieśmiertelność (futura immortalitas $)^{134}$. Augustyn bardzo wyraźnie poucza o tym słowami:

„Uleczone bowiem ciało, którego oczywiście oczekuje się od Pana, nastąpi na końcu przy zmartychwstaniu umarłych. Wtedy to, co żyć będzie, nie umrze, wówczas to, co wyzdrowieje, nie zachoruje, wtedy to, co się nasyci, nie będzie ani łaknąc ani pragnąć, wówczas to, co się odnowi, już nie zestarzeje się"”35.

Mając na uwadze to, że pełnia uzdrowienia nastąpi w wieczności po zmartwychwstaniu ciał, Augustyn tak oto uczy swych słuchaczy:

„Uzdrowienie nasze zaczęło się w wierze; doskonałe się stanie, gdy to, co skazitelne, przyoblecze się w nieskazitelność. Na razie jest to nadzieja, nie rzeczywistość. Kto jednakowoż cieszy się nadzieją, osiągnie i rzeczywistość; kto zaś nie ma nadziei, ten nie dojdzie do rzeczywistości"136.

Zdrowie człowieka osiągnie swoją doskonałość zatem wówczas, kiedy cały człowiek przyodzieje się w nieskazitelność. W doczesności człowiek, krocząc drogą wiary, przyszłą doskonałość uzdrowienia posiada niejako w nadziei, a nie w rzeczywistości. W tym kontekście Augustyn poucza w następujący sposób:

${ }^{131}$ Por. tamże 3, 3, NBA 24/1, 46.

${ }^{132}$ Por. A. Eckmann, Dobroć i piekno ludzkiego ciała w pismach świętego Augustyna, w: tenże, Symbol Apostolski w pismach świętego Augustyna, Lublin 1999, 156.

${ }^{133}$ Por. In Joannis Evangelium tractatus 64, 1, NBA 24/2, 1134.

${ }^{134}$ In Joannis Epistolam ad Parthos tractatus 2, 10, NBA 24/2, 1680,.

${ }^{135}$ In Joannis Evangelium tractatus 17, 1, NBA 24/1, 390, PSP 15, 248; por. J. Edling, Cielesnoduchowa struktura czlowieka $w$ swym wymiarze historyczno-rewelatywnym wg św. Augustyna, PreChr 8 (1999) 203-205.

${ }^{136}$ In Joannis Epistolam ad Parthos tractatus 8, 13, NBA 24/2, 1808, PSP 15/2, 475. 
„[...] odkupienie naszego ciała, o którym mówi Apostoł Paweł ${ }^{137}$, lecz i zbawienie dusz naszych, o którym mówi Apostoł Piotr ${ }^{138},[\ldots]$ w tym czasie i w tym śmiertelnym życiu raczej używa się w nadziei, niż w rzeczywistości się je posiada. W tym jest różnica, iż zewnętrzny nasz człowiek, tj. ciało jeszcze podlega skażeniu; wewnętrzny zaś, tj. dusza odnawia się z dniem każdym. I tak, jak oczekujemy nieśmiertelności ciała i przyszłego zbawienia dusz, choć już otrzymujemy zadatek, mówimy, iż zostaliśmy zbawieni, tak też winniśmy się spodziewać, że poznamy to wszystko, co Jednorodzony usłyszał od Ojca, choć Chrystus powiedział, iż się to stało"139.

Mając na uwadze to, że Autor homilii w kontekście In Joannis Evangelium tractatus 73 Jezusa - Zbawiciela przyrównuje do lekarza, a realizowane przez Niego dzieło zbawcze do procesu leczenia ${ }^{140}$, można przytoczoną wypowiedź zinterpretować w kluczu metafory leczenia. A zatem pełnia uleczenia, jakiego w życiu człowieka dokonuje Chrystus, nastąpi w wieczności. W ziemskim wymiarze człowiek, ciesząc się zadatkiem przyszłego szczęścia, w nadziei oczekuje doskonałego zdrowia duszy i ciała. Z tej racji „,całe życie dobrego chrześcijanina jest świętą tęsknotą"141 za ostatecznym celem. Jak uczy Augustyn, człowiek, aby mógł osiągnąć ów cel, powinien wytrwale kroczyć drogą wiary, nadziei i miłości, która w doczesności pozwala otworzyć się na działanie Jezusa - Boskiego lekarza ${ }^{142}$.

Analizując zawarte w homiliach do Ewangelii i Pierwszego Listu Jana Apostoła nauczanie Augustyna na temat duchowej choroby człowieka, zauważamy, że Autor homilii wiele uwagi poświęca także kwestii duchowego uzdrowienia człowieka. W tym kontekście Biskup Hippony poucza swoich słuchaczy, że człowiekowi, dotkniętemu duchową chorobą, czyli grzechem, nie było w stanie przynieść uzdrowienia Prawo Mojżeszowe. Tym, który przyniósł uleczenie człowiekowi z duchowych dolegliwości, jest Jezus Chrystus, określany przez Augustyna mianem lekarza (medicus) oraz lekarstwa (medicamentum, medicina de coelo veniens).

Uzdrowienie człowieka z duchowej choroby stało się możliwe, jak poucza Augustyn, dzięki Wcieleniu Jezusa Chrystusa-Słowa Bożego oraz podjętej przez Niego zbawczej męce i śmierci. Przestrzenią aktualnego działania

${ }^{137}$ Augustyn cytuje wcześniej następujące fragmenty nauczania Pawła Apostoła: 1Kor 13, 10;

Tt 3, 15; Rz 8, 24; Ga 5, 4.

${ }^{138}$ Augustyn przytacza wcześniej fragment z 1P 8, 9.

${ }^{139}$ In Joannis Evangelium tractatus 86, 1, NBA 24/2, 1272, PSP 15/2, 191.

${ }^{140}$ Por. tamże 73, 3, NBA 24/2, 1192-1194.

${ }^{141}$ In Joannis Epistolam ad Parthos tractatus 4, 6, NBA 24/2, 1716, PSP 15/2, 425.

${ }^{142}$ Por. In Joannis Evangelium tractatus 124, 5, NBA 24/2, 1614-1620. 
Jezusa, jako Boskiego lekarza są natomiast sakramenty, dzięki którym człowiek może otrzymać łaskę uwolnienia z niewoli grzechów, czyli uzdrowienia $\mathrm{z}$ duchowej choroby.

Pełnię zdrowia, którego źródłem jest Jezus - Boski lekarz i lekarstwo z nieba, człowiek osiągnie dopiero po zmartwychwstaniu ciała na końcu czasów. Jego ziemskie życie, w którym poprzez przyjmowane z wiarą sakramenty zaczyna się realizować uzdrowienie duszy, jest zatem swego rodzaju - jak to określa Augustyn - „świętą tęsknotą" za ostatecznym celem. Pełnia uzdrowienia będzie dotyczyć zarówno duszy, jak i ciała.

\section{CHRISTUS EIN ARZT UND EINE ARZNEI AUS DEM HIMMEL IN DEN HOMILIEN DES HEILIGEN AUGUSTINUS ZUM EVANGELIUM UND ZUM ERSTEN BRIEF DES APOSTELS JOHANNES}

\section{(Zusammenfassung)}

Bei der Analyse der in den Homilien des Heiligen Augustinus zum Evangelium und zum ersten Brief des Apostels Johannes enthaltenen Lehre (In Iohannis Evangelium tractatus und In Iohannis Epistolam ad Parthos tractatus) über seelische Krankeit des Menschen merken wir, dass der Verfasser der Homilien viel Aufmerksamkeit der Frage der seelischen Heilung des Menschen schenkt. In diesem Zusammenhang belehrt Bischoff von Hippo seine Leser, dass Mosegesetz außerstande war, dem von seelischer Krankheit oder von Sünde betroffenen Meschen die Heilung zu bringen. Derjenige, der die Heilung der Seelenkrankheit dem Meschen brachte, ist Jesus Christus, bezeichnet von Augustinus als ein Arzt (medicus) und ein Medikament (medicamentum, medicina de coelo veniens).

Wie Augustinus belehrt, wurde die Heilung des Menschen von Seelenkrankheit dank der Fleischwerung Jesus Christus - Wort Gottes und Seinem erlösenden Leiden und Tod möglich. Der Raum der aktuellen Handlung von Jesus als Göttlicher Arzt sind demgegenüber Sakramente, dank denen der Mensch die Gnade der Befreiung von Sünden bekommen kann, das heißt die Heilung von Seelenkrankheit.

Die Gesundheit in vollem Umfang, deren Quelle Jesus - „Göttlicher Arzt” und „Arznei aus Himmel” ist, erreicht der Mensch erst nach Auferstehung des Körpers am Ende der Zeiten. Sein irdisches Leben, in dem die Heilung der Seele durch die mit Glauben angenommenen Sakramente zu realisieren beginnt, ist demnach - wie es Augustinus bezeichnet - ,heilige Sehnsucht” nach entgültigem Ziel. Die Fülle der Gesundheit wird sowohl Seelle als auch Körper betreffen. 